\title{
Advances in Chromatography
}

DOI: $10.1134 / \mathrm{S} 1061934811040186$

The volume of M.S. Tswett's selected works prepared by the Russian Academy of Sciences includes the major part of the body of the doctoral dissertation by the inventor of chromatography, defended in 1911. This voluminous dissertation was published as a separate monograph (Khromofilly v Rastitel'nom $i$ Zhivotnom Mire (Chromophylls in the Plant and Animal Kingdom), Warsaw, 1910)). Though the title of the book was not "chromatographic," it described the results of the author's work on the technique of chromatography. However, the first book devoted to this method is usually considered Zechmeister and Cholnoky's monograph published in German in 1937 [1]; it played a significant role in the development of chromatography, in the approval of its name, and the recognition of Tswett's priority.

The preparation for Tswett's selected was announced at the Conference on Analytical Chromatography and Capillary Electrophoresis, September 26-30, 2010, held near Tuapse (Krasnodar krai). There, in particular, it was noted that a number of conferences and meetings both in Russia and all over the world are devoted to chromatography. This is quite natural in view of the huge role played by chromatography, first of all, in solving problems of chemical analysis.

In recent years, most attention has focused on high-performance liquid chromatography (HPLC) as applied to organic analysis, especially of biologically active compounds. HPLC is continuously being enhanced, its potential grows via the use of new efficient versions (they have their own names); new stationary phases; adsorbent particles of very small size and perfect shape; short and monolithic columns; and ultrahigh pressures. We can see examples of very quick separations, down to 1-3 min. Sample preparation systems have been worked out. HPLC in combination with preconcentration is used in computerized online versions. Two-dimensional liquid chromatography is being developed. Sufficient progress was attained in the analysis of polymers (so-called critical chromatography). Works on liquid chromatography for separation and subsequent detection using microfluid chips are continuing. Spectrophotometric detectors are the most widely used in HPLC; many other detectors are also used, of which I would like to note electrochemical and mass spectrometric detectors, including the MS-MS version. The applications of HPLC at the level of scientific publications are shifting towards objects of molecular biology and biomedicine, and at the level of routine analyses, primarily to the analysis of environmental objects, pharmaceutical preparations, and other objects.

In gas chromatography (GC), numerous versions involving derivatization have been proposed, which extend the range of determined compounds. Rapid GC (ultrahigh pressure, high flow rates of carrier gas) is being used more and more widely. Two-dimensional GC occupies an important place. Methods of compound identification are undergoing sophistication. Among numerous fields in which GC is applied, in addition to the main ones, such as monitoring in the chemical or oil refining industry, I would like to note numerous, not so abundant areas, such as analysis of exhaled air or the detection of explosives. By the way, the latter direction was considered in the recently published monograph on Extralaboratory Chemical Analysis [2].

The Russian chromatographic community is numerous and strong; its numerous achievements are not only well known but also highly appreciated by experts. We need only recall A.A. Zhukhovitskii, A.V. Kiselev, and V.A. Davankov, to say nothing of Tswett. Many books on chromatography have been published in Russian, including translations of foreign works. Many researchers have successfully worked in this field, for example, V.G. Berezkin. The Scientific Council on Chromatography of the Russian Academy of Sciences (in recent years, on Adsorption and Chromatography) plays an important role. The active members of the council deserve major thanks.

In 2009, the system of scientific councils of the Russian Academy of Sciences in chemistry and materials sciences was transformed; now chromatography is guided by the Scientific Council on Analytical Chemistry (SCAC). This integration should at least be used for a uniform system of conferences on chromatography and for unification of nomenclature. Recently, the SCAC has approved the Recommendations on Terms in Analytical Chemistry [3]. The noun "analysis" and verb "to analyze" in particular are recommended for use only with objects of analysis, water, soil, rock, air, urine etc., rather than with the components to be separated and determined (analytes). A similar recommendation was in due time made by the Organizing Committee of the Pittcon series conferences. The handbook Kto est' kto v rossiiskoi analiticheskoi khimii. Doktora nauk (Who's Who in Russian Analytical Chemistry: Doctors of Science) [4] 
includes data on many doctors in chromatography. The book Khimiki-analitiki o sebe i o svoei nauke (Analysts about Themselves and Their Science) [5], also prepared under the aegis of SCAC, includes perfect papers by Davankov and Berezkin, well-known chromatographists.

The above-mentioned conference was successful; it included brilliant presentations by both distinguished researchers and beginners.

\section{RERERENCES}

1. Zechmeister, L. and Cholnoky, L., Die chromatographische Adsorptionmethode, Vienna: Springer, 1937.

2. Problemy analiticheskoi khimii (Problems of Analytical Chemistry), vol. 13: Vnelaboratornyi khimicheskii analiz
(Extralaboratory Chemical Analysis), Zolotov, Yu.A., Ed., Moscow: Nauka, 2010.

3. Recommendations on Terms in Analytical Chemistry, Zh. Anal. Khim., 2010, vol. 65, no. 11, p. 1229 [J. Anal. Chem. (Engl. Transl.), vol. 65, no. 11, p. 1203].

4. Kto est' kto v rossiiskoi analiticheskoi khimii. Doktora nauk (Who's Who in Russian Analytical Chemistry: Doctrors of Sciences), Zolotov, Yu.A. and Shirokova, V.I., Eds., Moscow: LKI, 2010-2011.

5. Khimiki-analitiki o sebe i o svoei nauke (Analysts about Themselves and Their Science), Zolotov, Yu.A. and Shaposhnik, V.A., Eds., Noscow: Librokom, 2010-2011.

Yu. A. Zolotov 